\title{
The phenomenon of happiness in the Muslim tradition
}

\author{
Olga Nikolaevna Senyutkina ${ }^{1^{*}}$ \\ ${ }^{1}$ N. A. Dobrolyubova State Linguistic University of Nizhny Novgorod, Department of History and \\ Foreign Regional Studies, Nizhny Novgorod, Russia
}

\begin{abstract}
The need for research in the field of the designated problems is determined by the changing circumstances of the life of modern society on a global scale. In recent years, interfaith interactions in the world have not inspired optimism on improving intercultural contacts (one can mention the rejection of the policy of multiculturalism in Western Europe, terrorist attacks in France and other places, conflicts in the Middle East, etc.). The modern world demonstrates a blatant misunderstanding of others by social communities and the increasing conflict nature of the social environment. Hence the importance of academic developments of a humanistic nature. The author's goal is to show the general and specific understanding of the phenomenon of happiness in Muslim culture. The Muslim tradition sees the happiness of a Muslim in a deep faith in Allah and adherence to a behavioral model, the example of which is the Prophet Muhammad. It is in the observance of Sharia law that lies the foundation of stability in the life of the global ummah (Muslim community) itself, as well as its relations with the outside world. The work methods for this paper were, first of all, a content analysis of Muslim texts, a review of the historiography of the problem of understanding of happiness by Muslims, as well as direct contact with the Nizhny Novgorod Muslim Tatars during field studies expressed in in-depth interviews (1995-2000). The novelty of the work lies in the choice of the Muslim discourse of understanding happiness as the object of the author's consideration. As a result of the study, the author comes to confirm the idea that knowledge about the worldview attitudes of other cultures can help relieve tension in human communications at different levels. The data stated above are a confirmation of the Qur'anic tradition of finding means for peaceful communication between different ethnicities, as well as the works of Muslim scholars aimed at establishing good neighbor relationships in strengthening intercultural communication.
\end{abstract}

Keywords: happiness, Islam, interfaith interactions.

\section{Introduction}

"Each understood the meaning of happiness in his way. But one and all knew and understood that they must live honorably, work hard, and love and cherish the vast, happy land known as the Soviet Union" [1]. More than one generation of Soviet people was brought up with

\footnotetext{
*Corresponding author: senutkina@mail.ru
} 
these words of the famous children's writer Arkady Gaidar in the twentieth century. These words were considered the best in expressing an important idea, the idea of happiness and patriotism fused. On the one hand, every person has a right to their understanding of happiness. On the other hand, a single reference point is given for all Soviet people: the building of socialism as the happiest order of life in society. Until the 1990s, in Russia, it was not customary to talk about religion positively. However, under the conditions of changes at the end of the twentieth century, Russians were faced with the fact that confessional life began to intensify, and the voices of those who understood happiness in a completely different way than it had been dictated earlier became louder. Reviving their norms of religious life, Muslims were looking for new approaches to understanding the eternal category of happiness, referring to the Holy Book (the Qur'an), the Sunnah, the Hadith, the works of representatives of the Islamic civilization. The publication of primary sources, their study, the development of the thoughts of the wise people of the past began.

\section{Methods}

Certain prospects for researchers are opened by a methodology focused "on the study of layers of information hidden from awareness, relating both to universal cultural archetypes, acting as spontaneously acting stable structures for processing, storing and representing collective experience, and to those dependent on gender, ethnicity, axiological and psychological characteristics of personality" applied in one of the recent works by M.A. Abramova [2]. Interpretation of visual images allowed the scholar to examine and characterize the phenomenon of interest more closely. The proposed approaches can also be used in the study of Muslim ideas about happiness.

An analysis of the interviews that were taken by us from the Muslim Tatars of the Nizhny Novgorod region of the Russian Federation during repeated field expeditions to the southeast of the region, starting from the $1990 \mathrm{~s}$, confirmed that believers associated happiness with the pillars of Islam.

\section{Results and discussion}

A person who utters the well-known sacred phrase "There is no God but Allah, and Muhammad is His Prophet" enters that socio-cultural field, in which, according to a Muslim, they acquire true happiness. What is the reasoning for such a statement, which is usually given by the follower of Allah?

First of all, this is a reference to the text of the Holy Book, the Qur'an. "To whoever, male or female, does good deeds and has faith, We shall give a good life and reward them according to the best of their actions" [3]. That is, a believer (no matter if it is a man or a woman) who does good will be given a happy life. In this earthly life, they will see a meaning to it, they will be peaceful, experience joy will be full of inspiration. Later in the afterlife, they will be gifted to a greater extent than on Earth.

We are talking about happiness in both worlds: in earthly life and life after death. According to Muslims, adherence to religious norms gives the possibility of happiness in the eternal world. These ideas are constantly replicated in the educational activities of representatives of the Islamic world [4].

Sometimes the statements of Russian Muslims sound quite categorical: a non-believer is doomed to an unhappy life. "It is atheism that makes people unhappy, this is our thesis (highlighted by us - author). Although non-believers may be happy and smile, this is a temporary state. The fact is that their joy is associated with specific material things and phenomena. The joy of an atheist happens when they have bought a new car, a cottage, a 
bedroom set, and so on. The person is very happy, satisfied because their dream came true, they have bought what they had dreamed of. However, the feeling of novelty, which creates the illusion of joy from material acquisitions, soon disappears. No matter how beautiful the new kitchen set is, after a month it becomes familiar and commonplace. The feeling of joy goes away ..." [5]. Thus, at the ordinary level, the explanation of the difference in the understanding of happiness among believers and atheists sounds rather harshly concerning people outside the religious communities.

The difference in the religious and secular understanding of happiness, indeed, is that in one case, thoughts about the other world are more important, and in the other case people care more about the earthly world. One of the modern authors and educators writes: "The essence of Muslim happiness lies in caring not only about this world but also about the future, the one that happens next, the life after death. Of course, Muslims see the source of their happiness in faith in Allah. As He says in the Qur'an: "All believers in Allah and on the last day and doing (a good deed), they do not know neither fear nor contrition!" I would like to give an example of how Muslims perceive life. "As follows from the saying of the Messenger of Allah, peace, and blessings of the Almighty be upon him: 'Wondrous is the affair of a believer, as there is good for him in every matter. This is not the case for anyone but a believer. If he experiences pleasure, he thanks Allah and it is good for him. If he experiences harm, he shows patience and it is good for him.' This is the whole essence of the life of a Muslim. They believe that everything good and bad is from Allah. They live with these thoughts" [6].

Realizing that following the pillars of Islam gives a Muslim a feeling of happiness, the believer considers it necessary to build a sufficient number of new mosques as places of worship for Allah and prayer. Therefore, one should not be surprised that a call has been announced in Russia today to pay special attention to the construction of religious buildings. The Spiritual Directorate of Muslims of the Russian Federation (DUM RF) plans to build congregational mosques in all cities with a population of one million and the capitals of the constituent entities of the Russian Federation. Interest in the Hajj is growing every year. In the face of a pandemic, Muslims are demonstrating their commitment to zakat, helping those in need.

Developing the theme of happiness, talking about its acquisition, Muslims pay special attention to the family, recognizing its importance in earthly realities. If we talk about Russian Muslims, they, in particular, are looking for examples and paragons of the happy life of families in the history of their peoples [7].

The unity of the Islamic world is a global issue for Muslims today, it is also associated with the problem of believers' perception of the surrounding socio-cultural space, to what extent it allows them to be happy. To what extent can it bring one closer to the implementation of the principle "All Muslims are brothers"?

There is interest in the problem of Islam and anthropology in the academic community. One researcher writes: "Muslim society or societies? Islam or Islams? ... What is more important for central Islamic practices and beliefs in different social contexts, similarity or difference? An uncontested theological discourse common to all Muslims or a controversial one?" [8] The more scholars deal with the anthropology of Islamic life, the more powerful the antidote to Islamophobia, the more positively it affects the life of the Muslim community itself. In addition, it should be noted that modern Russian Muslim young people are moving away from traditional culture and are increasingly interested in the life of the Islamic world on a global scale.

Happiness is a concept that was considered in medieval Arab and Muslim thought. Today our contemporary Franco-Algerian scientist Muhammad Arkun (1928-2010) recalled this and revived in our memory the main ideas of the thinkers of the past [9]. Indeed, an appeal to the Muslim thought of the past is typical for modern scholars [10-14]. An interesting 
aspect of the study of the phenomenon of happiness is presented by the study of the development of the ideas of medieval Muslim thinkers today. For example, one of the works compares the views of Al-Farabi and our contemporary philosopher A. Kasymzhanov [15].

As the authors note, "A. Kasymzhanov... sees happiness as the freedom and independence of the people with simultaneous involvement with humanity, as harmony with oneself, people, and the world. Both teachers of wisdom regard happiness not as an individual but as a collective phenomenon. The art of being happy can and should be studied in the same way as philosophy as the pinnacle of beauty and the culture of thinking. The creative and life path of Al-Farabi and A. Kasymzhanov is a textbook of life for self-developing people and, first of all, for the younger generation. Being happy is one of the main values of today's youth. The ideas of the teachers of wisdom can teach to be human, to communicate, to remain human in the digital world, improve the ethics of the digital world and become worthy, digitally literate citizens" [15].

Some of the research results can be presented in the form of a small table.

Table 1. Factors influencing the achievement of happiness in the understanding of a Muslim

\begin{tabular}{|l|l|}
\hline The nature of the influencing factor & \multicolumn{1}{c|}{ Influence factor content } \\
\hline Individual & The depth of a Muslim's faith \\
\hline Individual & $\begin{array}{l}\text { The level of knowledge of the dogma and ritual side of } \\
\text { Islam }\end{array}$ \\
\hline Social & The state of the microclimate in the mahalla (parish) \\
\hline Political & $\begin{array}{l}\text { The relationship between the state and the society in } \\
\text { which the Muslim lives }\end{array}$ \\
\hline
\end{tabular}

\section{Conclusion}

There is certainly an interest in the topic raised in this paper. Judging by its relevance, it quite fits into the category of those challenges of recent times, to which modern society should give answers.

An analysis of interviews taken from Muslims shows that their understanding of happiness is dominated by religious discourse. The wealth of a person in earthly life is determined in the spirit of the Muslim tradition, namely: true wealth is the wealth of the soul. This brings Muslims closer to people of other cultures.

Some restrictions on the development of the topic indicated in the title of the paper are imposed by the lack of works of modern Muslim thinkers translated into Russian, which is important for Russian-speaking scholars. However, it seems that the same problem exists among researchers from other non-Muslim countries outside of Russia.

In the future, studies of the phenomenon of happiness in different cultures can contribute not only to a better understanding of each other by people living on Earth, but also to solve the issues of including theology in the socio-cultural space of the world community.

\section{References}

1. A.P. Gaidar, Chuk i Gek. Rasskazy [Chuk and Gek. Stories] (ROSMEN, Moscow, 2019)

2. M.A. Abramova, Monitoring Obshchestvennogo Mneniya: Ekonomicheskie i Sotsialnye Peremeny[Opinion Monitoring: Economic and Social Change], 1, 51-77 (2020). https://doi.org/10.14515/monitoring.2020.1.04.

3. Koran [The Qur'an]. Translated from Arabic by academician I.Yu. Krachkovsky (SP IKPA, Moscow, 1990) 
4. Schaste s tochki zreniya islama [Happiness from the perspective of Islam] (2014). Accessed on: September 01, 2019. [Online]. Available: https://islamtoday.ru/veroucenie/scaste-s-tocki-zrenia-islama/

5. M. Yakupov, Istinnoe schaste v Islame [True happiness in Islam] (2017). Accessed on: June 01, 2021. [Online]. Available: https://islamdag.ru/analitika/46925.

6. Nastavleniya. Sut musulmanskogo schastya [Instructions. The essence of Muslim happiness]. (2012). Accessed on: November 11, 2019. [Online]. Available:

http://www.info-islam.ru/stuff/religija/nastavlenija/sut_musulmanskogo_schastja/12-1$0-722$

7. A.A. Zakirov, Minbar. Islamskie issledovaniya, 5(2), 75-83 (2012)

8. C. Houston, Islamologiya, 8(1), 9 (2018). https://doi.org/10.24848/08.1.01.

9. M. Arkoun, Humanisme et islam: combats et propositions (Vrin, Paris, 2005)

10. E.V. Khazieva, Social and humanitarian knowledge, 10, 182-190 (2016)

11. M. M. Khairullaev, Abu Nasr Al-Farabi (Nauka, Moscow, 1982)

12. R. D. Ardakani, Farabi - osnovopolozhnik islamskoi filosofii [Farabi as the founder of Islamic philosophy]. Translated from Persian by A. Absalikov (Sadra, Moscow, 2014)

13. G. M. Mutanov (Ed.), Nauchnoe nasledie al-Farabi: (kommentarii k trudam) [Scientific heritage of Al-Farabi: (commentaries to his works)] (Qazaq wn-ti, Almaty, 2020)

14. Zh. Altaev, Al-Farabi - velikii myslitel Vostoka [Al-Farabi, the great thinker of the East] (Qazaq wn-ti, Almaty, 2018)

15. G. Myamesheva, K. Elzhan, Al-Farabi, 4(72), 3-11 (2020)

https://doi.org/10.48010/2020.4/1999-5911.01. 